\title{
SEVEN VOTYAK CHARMS
}

\section{Vladimir Napolskikh}

One of the elements of ancient Votyak paganism surviving till now is the traditional healing and sourcery. One may suppose that there is now hardly one living Votyak village without practioners (or, at least, those pretending to be practioners) of this arts. The trust in their power is, as a rule, generally accepted by the local population, especially - by the women and old people - and is continually confirmed by successes of more skilled healers contrasting with the permanent lacks and shortcomings of the official medicine. Many facts seem really to prove the existance of some "power", though the mechanism of its actioning stays to be unclear. Surely, we deal here with a display of extrasensor practice based on so-called "bio-energy", which can be used when the healer is skilled in the art and the patient has enough trust in it.

The common Votyak word for the healer (or witch-doctor) is emjas'kis' "healer" - a participle (= nomen agentis) from emjany; "to heal" - or pel'l'as'kis' "blower" - a participle from pel'l'as'kyny "to blow"; the last word describes one of the main ways of magic treatment, well-known throughover all the Europe, when the healer blows upon the water with charming and gives it to the patient to drink. This is a good illustration to the fact, that the Votyak notions about healers as well as those about the witchcraft (if not to say - all the so-called Votyak pagan religion) had developed as a part of common-European culture, under the dominating influence of neighbouring peoples, the Tatars and the Russians with their folk religions, formed in frames of official Islam and Christianity.

Though the healers - and it seems to be an old traditional feature - do never use to demonstrate their power in public, they are always highly respected and guarded (especially - during the Soviet age) by the local population because of being regarded as good people who can never make any harm. Thus, they stay in opposite to the witchs or sourcerers (vot. vedin /vegin < rus. vedun "witch, sourcerer (masc.)").

The general opposition between pel'l'as'kis' and vedin as between good and evil strengths compiles with a series of concrete. oppositions. While the healer deals only with people of our world and acts only for their purposes and needs, the sourcerer is believed to contact with the dead and to be able to return to this world after her (his) own death, especially - during the Great Thursday night before the Easter. Therefore the sourcerers are called somewhere shai vyle vetlis' - lit. "(the one, who) goes to the cemetery, cemetery frequenter". While the healer appears always as a concrete man or woman never changing his (her) image, the sourcerer uses to turn into a bird or an animal (oftener into a goose or a cat) making her evil business. A healer, being asked by somebody (not a stranger, of course) for his help, would hardly be reticent or deny his ability - while a sourcerer, though her evil activity might be well known to everybody in the village, would never own it up. When somebody wants to become a healer, this may study the art after an old pel'l'as'kis' and succeed after some time: the one should just have some talant, be good-hearted and zealous and find a good teacher, - but nobody is believed to have become a vedin by the one's own will. This evil gift is transmitted from one to another by magic way, very rarely with asking the recipient's agreement. Vedin can't die and suffers hard until the gift passes to another person, and this one can do nothing against when obtaining it. Also a good-hearted person after having received the gift has from time to time to harm at the trees if not the people. All the sourcerers I heared about were women (though the people believe that a man is able to be vedin too) - and among healers there were some men, and there is no doubt, that some seventy years ago it was possible to find even more men-healers, but the wars of the XX century had greatly reduced the number of old men. 
Treating a disease the Votyak healers spell peculiar charms -pel'l'as'konjos - lit. "blowings". These short texts are very interesting for philologists and anthropologists because they presumably can reserve ancient features of traditional poetic system and mythological worldview. Most of the Votyak charms known today in the scientific literature had been written in the end of the XIX beginning of the XX century. Perhaps, the best collection was presented by Bernat Munkacsi in his "Votjak nepkoltesi hagyomanyok". Nowadays it is not too easy to collect new charms: for example, in brilliant collection of Votyak texts edited by Dr. V.Kelmakov and collected by himself and his students one can find only five charms among 250 texts. This situation is not explained, as it might be supposed, by degradation of traditional quackery, but by the fact, that the healers have systematically been persecuted by the Soviet and communist functionaries and this have made them to keep their skill in secret, avoiding every stranger and newcomer even more than it was done traditionally. Only during last five-six years the folk medicine became acknowledged by the official medicine and highly esteemed healers have been de facto allowed to practice their art.

Here I am going to present seven Votyak charms collected by me in village Dym-Dym Omga of Vyatskie Polyani district of the Kirov government of Russia in winter 1991.

I came to Dym-Dym Omga for the first time in the frosty February of 1991. It was only a short reconnoitring trip, I planned to collect some materials on the traditional beliefs and calendar rites of local Votyaks, and only pen and paper were my tools.

Dym-Dym Omga is a big village situated not so far from the lower reaches of the great Vyatka river, which, perhaps, gave its name to one of the great Votyak tribes - Vatka. The name Dym-Dym Omga means "original, real Omga, Omga of worth", where Omga is a clan name. The village was founded, according local legends, about two hundreds years ago by three Votyak families of the Omga clan (I use the word "clan") to translate the Votyak vorshud) who came from North-East, down a small Kazan' river, where are situated other villages of the Omga clan - for example, the neighbouring Kazan Omga (Omga -(village) (on the river) Kazan'), Sjöd Oshmes Omga ("Omga (village) (near a) black water-spring"). Though the village was founded by Votyaks, the Russians came to live there very early too and the population had been mixed from the very beginning. However, the two nations lived their own ways and preserved their original spiritual culture notwithstanding the fact, that the Votyaks had been christianized for at least two hundred years ago. During the Soviet times, when the small villages around became deserted, their Russian and Tatar inhabitants came to live here, and now only less than a half of the villagers here are the Votyaks.

During a week I met old Votyaks and Russians writing stories about their old life and already my trip to be finishing, when a Votyak old lady recommended me to visit Zinok apai ("aunt Zinok") who was said to be a good healer and, being very old, could also answer my question the best.

Zinaida Plotnikova, or, according to Votyak tradition Zinok apai, lived with her grandson's family in a new house near the village school. She was really old enough (born in 1907), but when I entered the house and introduced myself, I found a lively, talkative old woman, who cooked for all the family, looked after the children and also found time to spin. We had long and interesting conversation and, step by step, came to the theme of traditional medicine. Greatly surprised was I, when the old healer began to tell me her secrets citing charms without any fear and reserve! On the next day I had to leave and therefore tried to write down as much as possible. I asked her about the ways of studying the art of healing, and she said that she could even teach me - no matter, that young, a man (she was tought by man herself) and a Russian (the knowledge of Votyak language was enough). Unfortunately, we had not so much time to conversate, to tell nothing about the teaching: she was very busy about the house. "This summer, - said she,- I am going to live alone in 
my own small cottage with my geese and sheep - you may come here to follow your work and to study a bit the art, if you want". Certainly, I received the invitation, and we parted till August, when, I hoped, I should collect perhaps my best field materials.

The 19th of August 1991 had been the date when I started to Dym-Dym Omga next time. It was not great pleasure to find myself in a village without any non-official information in the days of communist putch, but this had been the fate. I alighted from the bus in the village square and asked an old woman staying in a long line near the local shop for bread and wine, where is Zinok apai's house. "O, my son, - was the answer,- she died this spring, in April, don't you know?"

Today I think, that already in February she felt her death coming, and this was the reason of her openness. Nevertheless, we failed...

On the 20th of August I heared Yeltsin by radio, realized the truth of Moscow events and took the train to Moscow, but I had been late there too...

Thus, I have nothing but seven charms written by hand. I think, they should be published in memory of a good old woman, Votyak healer Zinaida Plotnikova, Zinok apai.

1 .

Sometimes a baby may be frightened by a sudden dog's barking or goose's cry and the baby's soul, urt goes away, they say.Urt is soul-double-ganger, responsible for mental helth and conciousness in opposite to lul - soul-breathing, responsible for phisical life, when the last goes away the person dies. The baby always dreads, can't sleep, has apparently a headache. In this case a cup or a deep plate of water should be taken, holden above the baby's head and melted lead be pured onto the water, saying:

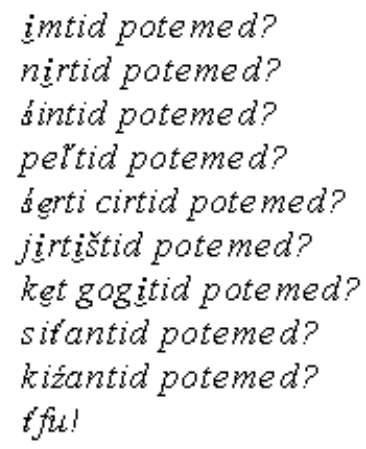

Through thy mouth thou went out?

Through thy nose thou w ent out?

Through thy eyes thou went out?

Through thy ears thou went out?

Through the back of thy neck thou went out?

Through the back of thy head thou went out?

Through thy navel thou went out?

Through thy anus thou went out?

Through thy uretra thou went out?

as like asking the soul. Thereafter the soul comes back.

2.

If there is a rupture of a baby bigger than a hen-egg, it should not be treated by a healer, operation should be done in a hospital. If the rupture is small, a besom from green abies twigs should me made and then, poking with the besom onto the rupture, should be said the next: 
badtźin pužimlen utuez cigiz ke, so intije u potiz na ke varia soka u med luoz. bad"zin kizlen utuez čigiz ke, so intije u potiz na ke varia soka u med luoz. bat'zin nitwpu utuez cigiz ke, so intije u potiz na ke vaŕa soka u med luoz. tfu!
If a branch of a big pine-tree was torn, and if a rupture appeared on that place, then Vanya's may be a rupture.

If a branch of a big fir-tree was torn, and if a rupture appeared on that place, then Vanya's may be a rupture.

If a branch of a big abies-tree was torn, and if a rupture appeared on that place, then Vanya's may be a rupture

3.

When a baby tears its navel (navel rupture), the next should be said:

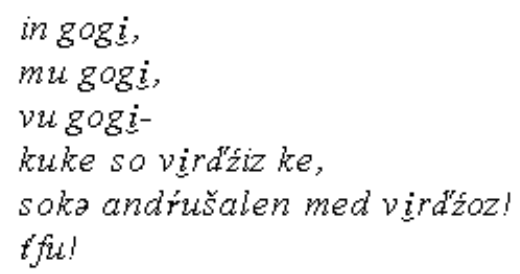

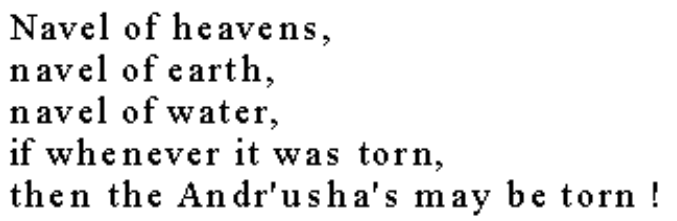

There after, massaging the baby's stomach with hands and with a bottle full of warm water, the navel rupture should be set right.

4.

When an evil eye was put on a baby, it can't sleep and cries - blowing upon some water the next should be said:

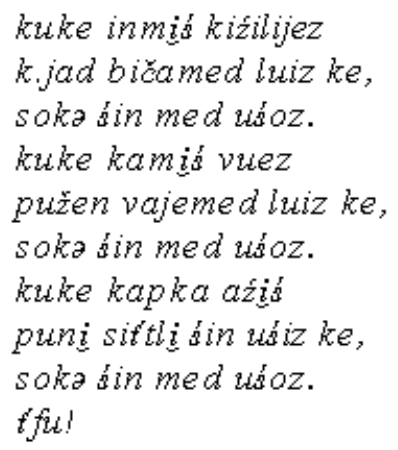

\author{
If whenever the stars from the sky \\ with thy hands thou could gather, \\ then may be put the (evil) eye. \\ If whenever the water from the Kam (river) \\ with a sieve thou could bring, \\ then may be put the (evil) eye. \\ If whenever upon before the gate (lying) \\ dog she at the (evil) eye was put, \\ then may be put the (evil) eye.
}

The name Kam is used in Votyak for big rivers: Ted'i Kam - "white kam", the Kama river and Vatka Kam - the Vyatka river. Here Kam means "Vyatka".

5.

When a baby's shoulder-blade comes out (dislocation, vot pin'ili pire - lit. "spoon-bone comes in"), the next should be said when setting it right: 


\author{
kuke gord atas \\ dzardatem iz jilin \\ silini cidaz ke, \\ soka parilili med piroz. \\ busisis kibodijez \\ gol ik kinid kutisa \\ jirčkikin merttemed luiz ke, \\ soka parilili med piroz. \\ šurín koškiś vuez \\ vallan karemed luiz ke, \\ soka paríli med piroz. \\ tfu!
}

If whenever a red cock on the top of a red-hot stone could survive staying, then may the shoulder-blade come out.

If a field thistle taken with thy bare hands thou could plant its head down, then may the shoulder-blade come out.

If flowing water from a river thou could make to flow upstreams, then may the shoulder-blade come out.

6.

If a man drinks a lot and uses to beat his wife, a thread from the rag which he used when washing in the sauna should be drawn out and sewn into his shirt, under the armpit, making three stitches without ties and saying the next:

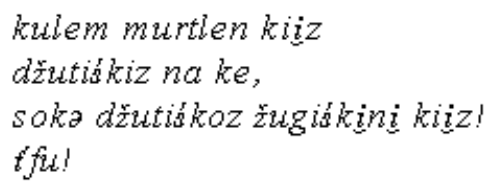

\author{
If a hand of dead man \\ would ever rise, \\ then will rise his hand to scuffle!
}

7.

If your hand has been burned you may take some coal from the oven and pouring this coal onto your hand around the burned place say thus:

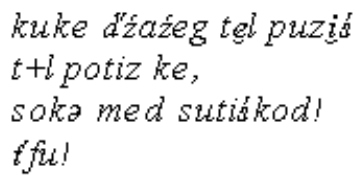

\author{
If whenever from an empty goose egg \\ a fire would come, \\ then thou mayst burn (it) !
}

\section{Warning! \\ Transcription some \\ words (technical \\ reason) in plain text \\ differs of \\ transcription used by \\ author. Here is \\ conversion table! \\ Sorry!}

emjaśkis emjani
pellaśkis perlaskini
sai vile vetlis
pertaśkonjos
sedošmes
ted"ikam
parilipire
Dim-Dim Omga

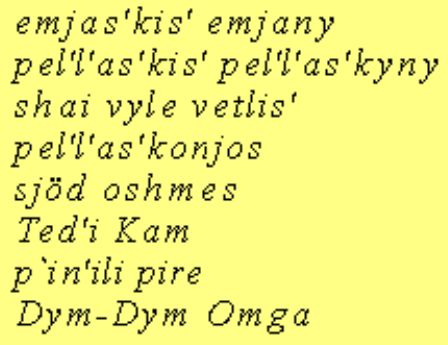

